\title{
Effect of Elevated Temperature on Fracture Toughness of Kimachi Sandstone
}

by Takahiro FUNATSU ${ }^{\mathrm{a}}$, Masahiro SETO ${ }^{\mathrm{b}}$, Hideki SHIMADA ${ }^{\mathrm{c}}$ and Kikuo MATSUI ${ }^{\mathrm{d}}$

a. Ph.D. student, Department of Earth Resources and Mining Engineering, Graduate School of Engineering, Kyushu University

b. Senior Planning officer, Planning Headquarters, National Institute of Advanced Industrial Science and Technology, Tsukuba 305-8567, Japan

c. Associate Professor, Department of Earth Resources and Mining Engineering, Graduate School of Engineering, Kyushu University

d. Professor, Department of Earth Resources and Mining Engineering, Graduate School of Engineering, Kyushu University

In order to understand the effect of elevated temperature on fracture toughness, fracture toughness experiments were carried out at increasing temperatures from room temperature to $200^{\circ} \mathrm{C}$ using the single edge-notched round bar in bending (SENRBB) specimen and the semi-circular bend (SCB) specimen of Kimachi sandstone. The paper firstly describes the methodology for the evaluation of level I fracture toughness and crack growth resistance curve. Crack growth resistance curve is also shown to consider the increase of the crack growth resistance with crack growth. The experimental results showed that fracture toughness of Kimachi sandstone did not vary significantly at temperature up to $125^{\circ} \mathrm{C}$ and increased with elevated temperature beyond $125^{\circ} \mathrm{C}$. The level I fracture toughness from the SENRBB testing increased by approximately $40 \%$ at $200{ }^{\circ} \mathrm{C}$ when compared to the value at room temperature. The variation of fracture toughness can be explained in terms of thermally-induced microcracks and dehydration of interlayer water and adsorptive water included in clay material such as montmorillonite. The thermally induced microcracks, which were confirmed under microscope, lower the fracture toughness due to decrease in crack growth resistance, while the dehydration of interlayer water and adsorptive water in the rock specimen, which were confirmed by measuring weight under several temperatures, raises the fracture toughness because of increase in bonding strength between the mineral particles. Based on the strain and Young's modulus measurements under elevated temperature, it was concluded that the dehydration of interlayer and adsorptive water and the thermally induced microcracks influenced on the fracture toughness of Kimachi sandstone.

KEY WORDS : Sandstone, Fracture Toughness, Elevated Temperature, Microcrack, Clay Material

1. 緒 言

近年，高レベル放射性廃棄物の地層処分や LPG, LNG の地下貯 蔵等の長期的な地下の利用に対する関心が高まっている。このよ うな地下岩盤の長期的な利用に関しては，その設計や健全性の評 価が改めて課題となっている。しかしながら, 岩盤構造物の長期 的な利用を考える上では, 従来, 設計や健全性の評価に用いられ てきた岩石の圧縮強度や引張強度等の強度特性のみならず，長期 的な安全性評価を行う必要性から岩石のクリープ特性や対象とな る地下の外力条件や環境条件により生じる応力腐食割れ等を総合 的に検討寸る必要があると考えられる。さらに, 通常, 岩石内部 には潜在き裂が含まれており，地下の環境条件や外力条件によっ て，長期的に潜在き裂の様相が変化し，岩盤構造物の安定性に影

* 2001 年 12 月 5 日受付 2002 年 8 月 8 日受理

1. 学生会員 九州大学大学院生 工学府地球資源システム工学専攻 博士後期 課程

2. 普通会員 産業技術総合研究所 企画本部

3. 普通会員 九州大学助教授 大学院工学研究院

4. 普通会員 九州大学教授 大学院工学研究院

[ 著者連絡先 ] FAX 0298-61-8766 (産総研)

キーワード : 砂岩, 破壊勒性, 温度, マイクロクラック，粘土鉱物
響を及ぼすものと考えられる。したがって, 岩石のき裂の進展抵 抗を示寸破壊勒性に関する検討も重要であると考えられる。

例えば，高レベル放射性廃棄物の地層処分では，地下 $300 \mathrm{~m}$ 以 深の地下に岩盤構造物を建設することが想定されている ( 原子力 委員会, 2000)ことから, 外力条件として高い地殼応力を考慮する 必要があり, さらに環境条件としては, 地下水質や廃棄体から放 出される熱等について考慮する必要がある。したがって, 地下岩 盤の長期的な安定性を検討寸る上では, これらの外力条件や環境 条件が岩石の力学特性に及ぼす影響について実験的に明らかにす る必要がある。本研究では, これらの外力条件と環境条件の中か ら, 環境条件の 1 つとして挙げた温度の影響に着目して実験的に 検討を行った。

ところで, 温度が岩石の破壊勒性や破壊強度に及ぼす影響につ いては，以下のような研究が行われてきている。

高温下の岩石の破壊勒性については, Meredith et al. は, 花崗岩 および斑レイ岩を用いて $20^{\circ} \mathrm{Cから} 400{ }^{\circ} \mathrm{C}$ 範囲でダブルトーショ ン試験による検討を行っている (Meredith et al., 1985)。その結果, 斑レイ岩の場合, 破壊靭性は $20{ }^{\circ} \mathrm{C} ら 100{ }^{\circ} \mathrm{C}$ 範囲で温度の上昇 に伴い増加するが， $100{ }^{\circ} \mathrm{C}$ 以上では温度の上昇に伴い低下寸るこ 


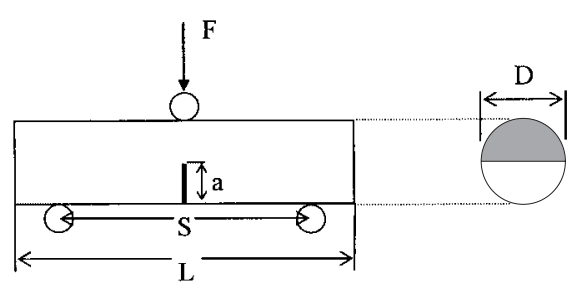

(a) SENRBB specimen (D: specimen diameter, a: notch length, L: specimen length, S: support span, F: loading force)

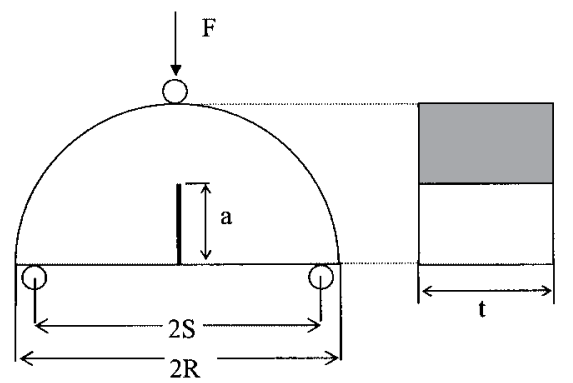

(b) SCB specimen (R: specimen radius, a: notch length, t: specimen thickness, 2S: support span, F: loading force)

Fig.1 Schematic diagrams of (a) SENRBB specimen and (b) SCB specimen.

とを，400 ${ }^{\circ} \mathrm{C}$ における破壊勒性は室温条件における破壊勒性の 60 $\%$ から $65 \%$ となることを示した。また，花崗岩の場合も同様に， $100{ }^{\circ} \mathrm{C}$ 以上の温度では, 温度の上昇に伴い破壊勒性が低下寸るこ と, $400{ }^{\circ} \mathrm{C}$ にいては破壊勒性が室温条件における破壊勒性の約 $40 \%$ に低下寸ることを示した。Al-Shayea et al. は，石灰岩につい て室温から $116{ }^{\circ} \mathrm{C}$ の範囲で SNBD(Straight Notched Brazilian Disk) 試験片を用いた圧縮試験 (Al-Shayea et al., 2000) を実施し破壊靭 性に及ぼす温度の影響について検討している。その結果，石灰岩 の破壊勒性は室温から $116^{\circ} \mathrm{C}$ 範囲では温度の上昇に伴い増加し, $116{ }^{\circ} \mathrm{C}$ における破壊勒性は室温条件における破壊勒性に比べて約 $25 \%$ 大きいことを示した。木下らは, 花崗岩, 安山岩, 凝灰岩の 3 種類の岩石を用いて, 室温から $200{ }^{\circ} \mathrm{C}$ までの範囲で一軸圧縮試験 を実施し(木下ら，1997)，花崗岩および凝灰岩では，一軸圧縮強 度, 静弾性係数およびポアソン比は温度上昇に伴って低下寸るこ とを示した。一方, 安山岩では, 一軸圧縮強度と静弾性係数は室 温から $200{ }^{\circ} \mathrm{C}$ 範囲では温度の上昇に伴い増加するが，ポアソン 比については温度依存性が明確に現れないことを示した。また, 酒井は大理石，花崗岩，凝灰岩，溶結凝灰岩の 4 種類の岩石を用 い, 室温から $600{ }^{\circ} \mathrm{C}$ までの範囲で一軸圧縮試験を行ない（酒井, 1987), 凝灰岩の圧縮強度と割線ヤング率は, 室温から $300{ }^{\circ} \mathrm{C}$ 範 囲では温度の上昇に伴い低下寸るが， $300{ }^{\circ} \mathrm{C}$ 以上では温度の上昇 に伴い増加することを，溶結凝灰岩では室温から $600{ }^{\circ} \mathrm{C}$ の範囲で 温度の上昇に伴い圧縮強度と割線ヤング率が増加すること, 大理 石および花崗岩の圧縮強度と割線ヤング率は温度の上昇に伴い低 下寸ることを示した。

岩石の力学特性に及ぼす温度の影響に関しては以上に述べたよ うな研究が行われてきているが，岩石の破壊勒性に及ぼす温度の 影響については花崗岩に代表される結晶質岩についての研究が主 で，堆積岩についてはほとんど研究事例がないのが現状である。

そこで本研究では, 従来の研究においてはほとんど対象となら なかった堆積岩について, 来待砂岩を用いて破壊勒性に及ぼす温 度の影響について検討を行った。

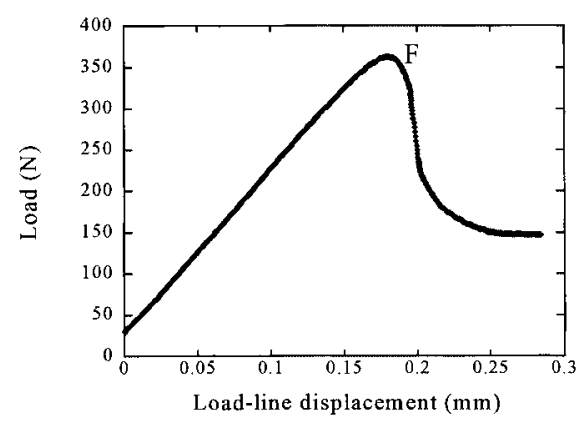

Fig.2 Typical load against load-line displacement curve for the SENRBB tests. (arrester orientation)

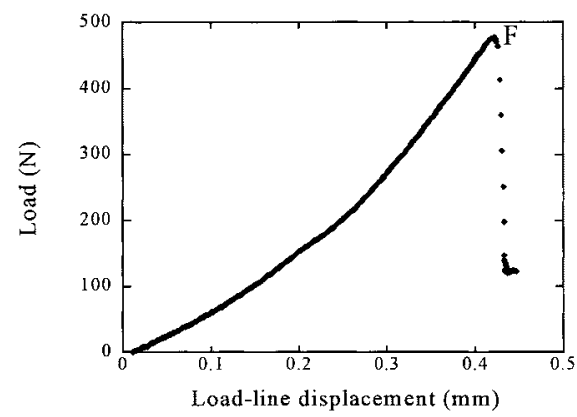

Fig.3 Typical load against load-line displacement curve for the SCB tests. (arrester orientation)

\section{2. 破壊勒性評価法}

本研究においては, 以下に述べる SENRBB(Single Edge-Notched Round Bar in Bending) 試験法および SCB (Semi-Circular Bend) 試験 法によって，レベル I 破壊勒性と R 曲線法による破壊勒性の評価 を行い，それに対する温度の影響を実験的に調べた。

\section{$2 \cdot 1$ レベル|破壊勒性の評価}

$2 \cdot 1 \cdot 1$ SENRBB 試験法による破壊勒性の算出 SENRBB 試験法は, 円柱形の試料に, 人工き裂として前縁が直線のストレー トノッチを有する試験片を用いる試験法である。SENRBB 試験片 の形状を Fig.1(a) に示す。試験では, 試験片を下部の 2 点の支点 ローラで支え，上部を 1 点のローラで載荷することにより曲げ荷 重を負荷した。破壊勒性の評価は, 試験時に記録した最大荷重お よび試験片寸法，下部の支点ローラ間の長さを用いて行った。

Fig.2 に SENRBB 試験により得られた荷重一変位曲線の一例を 示すが，同図の最大荷重 $F$ を用いて次式によりレベル I 破壊勒性 值 $K_{I C}$ を求めた (Ouchterlony, 1981)。

$$
K_{I C}=0.25(S / D) Y_{I}^{\prime} F / D^{1.5}
$$

ここで, 式中の $S$ は支点ローラ間の長さ, $D$ は試験片の直径, $Y_{I}^{\prime}$ は 無次元化された応力拡大係数であり次式で与えられる。

$$
Y_{I}^{\prime}=2(D / S)\left[450.8531 \rho^{2}(a / D)^{1.5}\right] /\left[(a / D)-(a / D)^{2}\right]^{0.25} \cdots
$$

ここで, $\rho=(S / D) / 3.33$ で, $a$ はノッチ長さである。

2・1・2 SCB 試験法による破壊勒性の算出 SCB 試験法は, 半円形の試料に人口き裂として前縁が直線のストレートノッチを 作製した試験片を用いる試験法である。SCB 試験片の形状を Fig.1(b) に示す。試験では, 試験片に対し下部を 2 点で支え, 上部 を 1 点のローラで載荷することにより曲げ荷重を負荷し, 試験時 に記録した荷重および変位のデータから破壊勒性を評価した。

Fig.3 に SCB 試験により得られた荷重一変位曲線の一例を示す が, 同図の最大荷重 $F$ を用いて次式によりレベル I 破壊勒性値 $K_{I C}$ 
を求めた (Chong and Kuruppu，1984)。

$$
K_{I C}=Y F(\sqrt{\pi a}) / 2 R t
$$

ここで, $R$ は試験片半径, $t$ は試験片の厚さであり, 式中の $Y$ は無 次元化された応力拡大係数でノッチ長さ $(a)$ と試験片半径 $(R)$ 比 $\alpha(\alpha=a / R)$ の関数であり次式で与えられる。

$$
Y=5.6-22.2 \alpha+167 \alpha^{2}-576 \alpha^{3}+929 \alpha^{4}-506 \alpha^{5}
$$

\section{$2 \cdot 2 \mathrm{R}$ 曲線法による破壊靯性の評価}

本研究では，2・1 に述べた方法によって主にレベル I 破壊勒性 の評価を行った。しかしながら，レベル I 破壊靭性においては，き 裂の成長に伴うき裂進展抵抗が増加する (松木ら，1989) 点につい て考慮されていない。そこで本研究では，き裂進展量とき裂進展 抵抗との関係であるき裂進展抵抗曲線 ( $\mathrm{R}$ 曲線) による破壊勒性の 評価についても併せて実施し，一部の結果についてレベル I 破壊 勒性との比較検討を行った。以下に，その $\mathrm{R}$ 曲線法による破壊靭 性の評価方法を述べる。

$\mathrm{R}$ 曲線法による破壊勒性の評価では，載荷一除荷一再載荷の繰 り返し載荷を行なうことにより得られる, 荷重一荷重線変位曲線 を用いる。Fig.4 に繰り返し載荷で得られた荷重一荷重線変位曲線 の一例を示すが， R 曲線法による破壊靭性の評価は次の (i) 〜 (vi) の手順で行なった。

（i）荷重一荷重線変位曲線の各サイクルの傾きから，各サイク ルの弾性コンプライアンス $(C=\Delta D / \Delta F)$ を算出する。

(ii) 求めた弾性コンプライアンスを, 平面ひずみヤング率 $\left(E^{\prime}=\right.$ $\left.E /\left(1-v^{2}\right)\right)$ と試験片直径 $(D)$ を用いて無次元化し, 無次元コンプ ライアンス $\left(C^{\prime}=C E^{\prime} D\right)$ を算出する。

(iii) あらかじめ実験的に算出しておいた無次元コンプライア ンス $C$ と $a / D$ との関係曲線と (ii) で算出した無次元コンプライア ンスとを比較して，各サイクルにおける $a / D$ 比を算出する。

(iv) $\mathrm{i}$ 番目のサイクルに対応する $\left(a_{\mathrm{i}} / D\right)$ とそのサイクルに対応 する除荷荷重 $\left(F_{\mathrm{i}}\right)$ を SENRBB 試験では式 (1), 式 (2) 中の $a / D$ と $F$ に代人することにより, $\mathrm{i}$ 番目のき裂進展抵抗 $\left(K_{\mathrm{i}}\right)$ を求める。

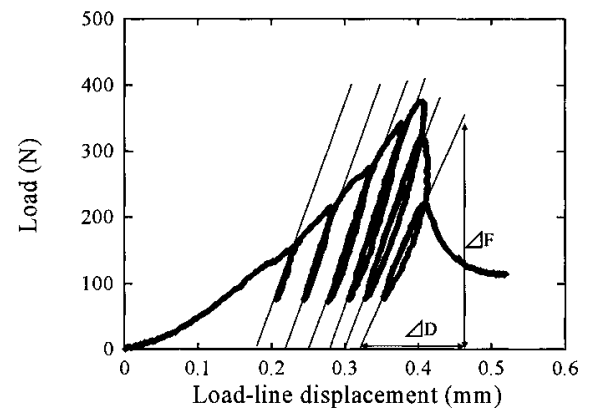

Fig.4 Typical load against load-line displacement curve in cyclic loading. (SENRBB tests, arrester orientation)

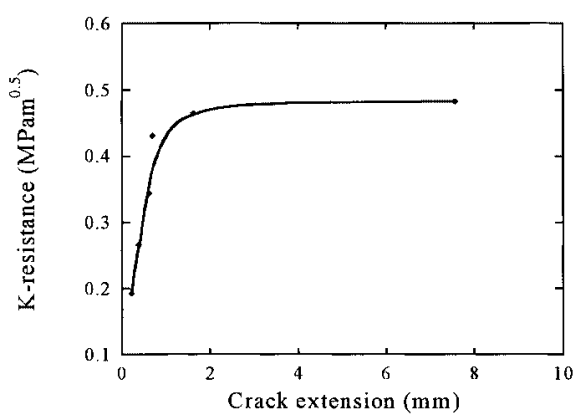

Fig.5 K-resistance curve using SENRBB specimen. (arrester orientation) （v） i 番目のサイクルにおけるき裂進展量 $\left(a_{\mathrm{i}}-a_{0}\right)$ を横軸にき裂 進展抵抗を縦軸にプロットし, Fig.5に示すようなき裂進展抵抗曲 線を描く。

（vi）このき裂進展抵抗曲線から, き裂進展抵抗がほぼ一定とな る值を破壊靭性として評価する。

\section{3. 実験の概要}

\section{$3 \cdot 1$ 岩石試料}

試験に用いた岩石は島根県産の来待砂岩である。本研究におい て用いた岩石の基礎的な力学物性值を調べるために, 一軸圧縮試 験, 圧裂引張試験, 弾性波速度測定を行った。一軸圧縮試験で用 いた試験片は，寸法が $300 \mathrm{~mm} \times 300 \mathrm{~mm} \times 300 \mathrm{~mm}$ の岩石ブロック に層理面に対して平行な方向および垂直な方向の 2 方向から内径 $30 \mathrm{~mm}$ のダイヤモンドビットドリルを用いてコアボーリングを 行った後, $75 \mathrm{~mm}$ の長さに切断し, さらに両端面の平行度が士 1 / $50 \mathrm{~mm}$ 以内になるようにグラインダーで整形した円柱形のもので ある。この試験片を $60^{\circ} \mathrm{Cで} 120$ 時間強制乾燥した後, 脱気を行い 試験に備えた。なお，一軸圧縮試験時に軸ひずみおよび横ひずみ を計測するために，ゲージ長 $5 \mathrm{~mm}$ の二軸型のひずみゲージを試 験片の相対する表面上の中心に 2 枚貼り付けた。Fig.6 に一軸圧縮 試験から得られた応力ーひずみ線図の一例を示す。同図に示すよ うに, 本研究では最大応力の $50 \%$ における応力一軸ひずみ曲線の 接線の傾きをヤング率 $E_{50}=\left(\sigma_{\mathrm{a}}-\sigma_{\mathrm{b}}\right) /\left(\varepsilon_{\mathrm{a}}-\varepsilon_{\mathrm{b}}\right)$ として算出し, 同 様に最大応力の $50 \%$ における軸ひずみと横ひずみからポアッソン 比 $v=-\varepsilon_{\mathrm{L}} / \varepsilon_{\mathrm{A}}$ を算出した。

引張強度を求めるための圧裂試験で用いた試験片は, 寸法が $300 \mathrm{~mm} \times 300 \mathrm{~mm} \times 300 \mathrm{~mm}$ の岩石ブロックに層理面に対して平行 な方向および垂直な方向の 2 方向から内径 $60 \mathrm{~mm}$ のダイヤモンド ビットドリルを用いてコアボーリングを行なった後, $30 \mathrm{~mm}$ 程度 の長さに切断したものを用いた。この試験片を $60{ }^{\circ} \mathrm{Cで} 120$ 時間強 制乾燥し脱気を行った後, 載荷試験を行った。弾性波速度測定に 用いた試験片は，一軸圧縮試験に用いた試験片と同一のものを用 いた。Table 1 にこれらの物性試験の結果を示す。同表によると,

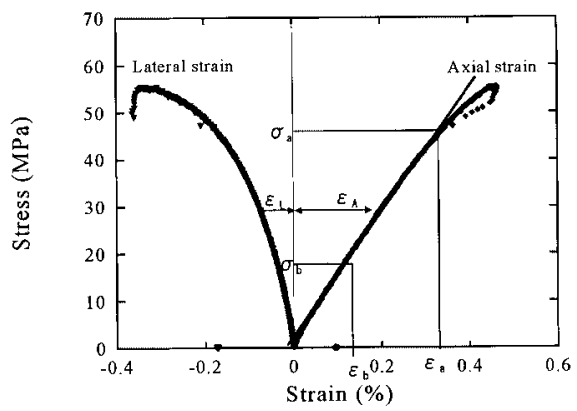

Fig.6 Typical stress-strain curve. (perpendicular to bedding plane)

\begin{tabular}{|c|c|c|c|c|c|c|}
\hline & $\begin{array}{c}\text { Relationship } \\
\text { between } \\
\text { bedding plane } \\
\text { and loading } \\
\text { direction } \\
\end{array}$ & $\sigma_{\mathrm{C}}(\mathrm{MPa})$ & $\sigma_{\mathrm{t}}(\mathrm{MPa})$ & $\begin{array}{c}\mathrm{E}_{50} \\
(\mathrm{GPa})\end{array}$ & $\nu$ & $\begin{array}{c}\mathrm{V}_{\mathrm{P}} \\
(\mathrm{km} / \mathrm{sec})\end{array}$ \\
\hline \multirow{2}{*}{$\begin{array}{l}\text { Kimachi } \\
\text { sandstone }\end{array}$} & 1 & $59.0 \pm 2.5$ & $4.82 \pm 0.12$ & $8.23 \pm 1.43$ & $\begin{array}{c}0.22 \pm \\
0.10\end{array}$ & $2.91 \pm 0.02$ \\
\hline & $1 /$ & $68.6 \pm 1.1$ & $4.89 \pm 0.40$ & $8.24 \pm 0.22$ & $\begin{array}{c}0.16 \pm \\
0.01\end{array}$ & $2.91 \pm 0.03$ \\
\hline
\end{tabular}

Table 1 Mechanical properties of Kimachi sandstone.

$\sigma_{C}$ : Uniaxial compressive strength, $\sigma_{i}$ Tensile strength, $E_{50}$ : Tangential Young's modulus at a half of compressive strength , $\quad \nu$ : Poisson's ratio, $\quad V_{P}$ : Velocity of P-wave 


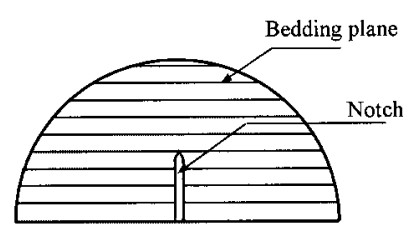

(a) Arrester

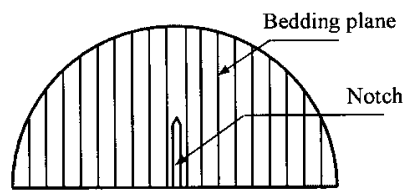

(b) Short transverse

Fig.7 Schematic illustrations of the principal crack orientations with respect to bedding planes. (a) Arrester, (b) Short transverse

本研究において使用した来待砂岩には異方性が存 在した。例えば, 一軸圧縮強度においては, 層理 面に平行に載荷したときの強度が，垂直に載荷し たときの強度と比較して約 $16 \%$ 高い值を示した。 そこで，SCB 試験片ではこの異方性を考慮して,

Fig.7 に示す arrester と short transverse の 2 種類の試験片を準備し た。試験片の準備においては, 同一の岩石ブロックから SENRBB 試験片では層理面に対して平行な方向から, SCB 試験片では層理 面に対し平行な方向と垂直な方向の 2 方向からコアボーリングを 行った。採取した岩石コアを, Fig1(a)，(b)に示寸形状に整形した 後, ダイヤモンドブレードにより厚さ $0.3 \mathrm{~mm}$ のノッチを作製し た。なお Fig.1(a) に示す SENRBB 試験片の寸法は $D=30 \mathrm{~mm}, L=$ $110 \mathrm{~mm}, S=83.3 \mathrm{~mm}, a=12 \mathrm{~mm}$ である。また, Fig.1(b) に示す $\mathrm{SCB}$ 試験片の寸法は, $2 R=60 \mathrm{~mm}, t=25 \mathrm{~mm}, 2 S=48 \mathrm{~mm}, a=15$ $\mathrm{mm}$ である。この試験片を $60{ }^{\circ} \mathrm{C}$ で 120 時間乾燥させた後, 試験時 の加熱により試験片内部の空気が膨張し被覆したシリコン樹脂 を破るのを防ぐために真空デシケータの中で脱気を行った。この 脱気に関しては, 脱気を行わなかった試験片を加熱したときシリ コン樹脂が破断したのに対して, 脱気を行った場合にはシリコン 樹脂の破断の減少が認められたことから, 効果があったものと考 えられる。

\section{$3 \cdot 2$ 試験装置および試験手順}

試験装置の概要を Fig.8 に示す。試験装置の最大荷重容量は 19.6 $\mathrm{kN}$ である。本試験では, 試験片をシリコンオイルで満たした試験 槽に入れ，一定温度条件で試験を実施したが，本研究において設 定可能な最高温度は $200{ }^{\circ} \mathrm{C}$ である。シリコンオイルがノッチや試 験片内部の空隙に浸入することを防ぐために, ノッチおよび試験 片をシールした。シールの方法としては試験片にシリコン樹脂を 塗布したが，塗布するシリコン樹脂がノッチ内部に浸入すること を防ぐために，ノッチの周りに紙製またはセロハン製のテープを 巻いた後, その上から試験片全体にシリコン樹脂を均一に塗布し た。

まず，試験片を試験用治具にセットし，固定のため約 $0.5 \mathrm{~N} の$ 荷重を負荷した。次に, 荷重および変位のゼロ点調整を行った後, 試験槽内に試験片および試験用治具を納め試験槽を密閉した。そ の後, 試験槽をシリコンオイルによって満たし, 試験槽中のシリ コンオイルを加熱して所定の試験温度条件を設定した。試験温度 条件を設定する際, 昇温速度が $200{ }^{\circ} \mathrm{C} / \mathrm{h}\left(3.3^{\circ} \mathrm{C} / \mathrm{min}\right)$ 以下では熱衝 撃による破壊が起こらないことが報告されていることから（山口
ら，1970)，本研究では熱衝撃による試験片の損傷を防ぐために昇 温速度を約 $1{ }^{\circ} \mathrm{C} / \mathrm{min}$ として加熱した。所定の温度に到達した後, 試験片内部の温度を均一にするために, その状態で 2 時間放置し, その後試験を開始した。試験片への載荷は, 荷重線変位速度を一 定 $(0.075 \mathrm{~mm} / \mathrm{min})$ とした条件で行い, 荷重が最大荷重に到達した 後残留強度状態になるまで載荷を行った。

また, 本研究での温度条件は, $50{ }^{\circ} \mathrm{C}, 75^{\circ} \mathrm{C}, 100{ }^{\circ} \mathrm{C}, 125{ }^{\circ} \mathrm{C}$, $150{ }^{\circ} \mathrm{C}, 175^{\circ} \mathrm{C}$, および $200{ }^{\circ} \mathrm{C} の 7$ 条件を設定した。なお, 荷重, 変位および温度のデータは試験機からコンピュータに送り, ディ スクに保存した。

\section{4. 結果}

本章では，まず， $4 \cdot 1$ および $4 \cdot 2$ において来待砂岩の破壊靭 性に及ぼすノッチ長さの影響と荷重線変位速度の影響について, 常温下で SENRBB 試験によって行った検討結果について述べる。 次に $4 \cdot 3$ では, 7 種類の温度条件の下で行った SENRBB 試験と SCB 試験の結果について述べる。すべての試験において同一条件 で最低 3 回試験を行い, 值を平均し標準偏差を評価した。

\section{$4 \cdot 1$ 破壊勒性に及ぼすノッチ長さの影響}

来待砂岩の破壊勒性に及ぼすノッチ長さの影響について実験的 に検討するために, SENRBB 試験片のノッチ長さ $(a)$ と試験片寸 法 $(D)$ の比 $(a / D)$ を, $a / D=0.2,0.4,0.5$, および 0.6 とした条件 でSENRBB 試験を行なった。Fig.9 は $a / D$ と破壊勒性との関係を 示す。同図に示すように, 来待砂岩の破壊勒性は, $a / D=0.2$ から 0.4 の範囲でほぼ一定の值を示したが, $a / D=0.5$ では, 来待砂岩 の破壊勒性は $a / D=0.4$ のときの破壊勒性と比べて約 $21 \%$ 低下し た。さらに、 $a / D=0.6$ では, $a / D=0.4$ のときと比べて来待砂岩 の破壊勒性は約 $38 \%$ 低下しており, 破壊勒性は $a / D>0.4$ の条件 においては、 $a / D$ の増加に伴って低下寸ることが分かった。なお、 この結果は, 過去に行われた破壊勒性に及ぼすノッチ長さの影響 に関する検討 (Sun et al., 1986) と同様な傾向であった。

\section{$4 \cdot 2$ 破壊勒性に及ぼす荷重線変位速度の影響}

来待砂岩の破壊勒性に及ぼす荷重線変位速度の影響について実 験的に検討を行なうために, 荷重線変位速度として $0.01 \mathrm{~mm} / \mathrm{min}$, 


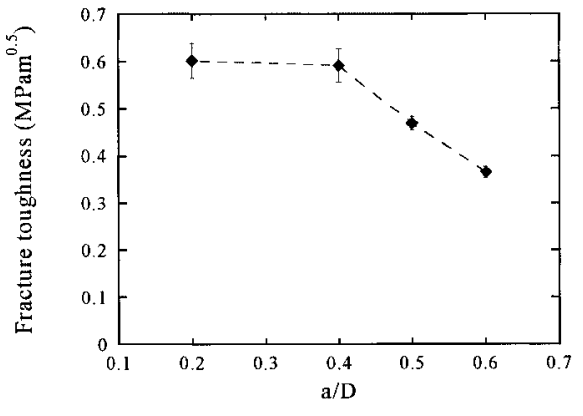

Fig.9 Variation of fracture toughness of Kimachi sandstone for SENRBB tests with notch length $(a / D)$.

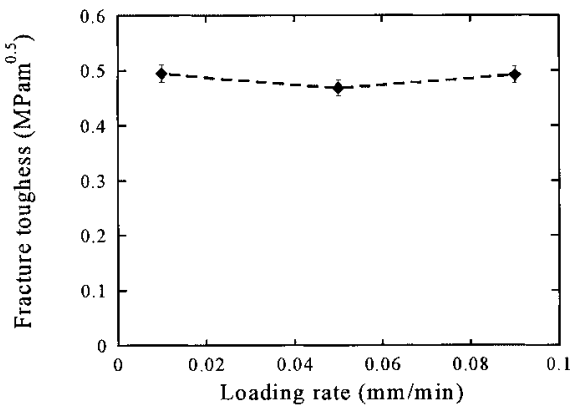

Fig.10 Variation of fracture toughness of Kimachi sandstone for SENRBB tests with loading rate.

$0.05 \mathrm{~mm} / \mathrm{min}$, および $0.09 \mathrm{~mm} / \min の 3$ 種類の条件を与えて, SENRBB 試験を行なった。Fig.10 は，荷重線変位速度と破壊勒性 との関係を示す。同図において示すように，来待砂岩の破壊勒性 は，荷重線変位速度が $0.01 \mathrm{~mm} / \mathrm{min}, 0.05 \mathrm{~mm} / \mathrm{min}, 0.09 \mathrm{~mm} / \mathrm{min}$ のいずれの条件においてもほぼ一定の值をとっており, $0.01 \mathrm{~mm} /$ $\min$ から $0.09 \mathrm{~mm} / \mathrm{min}$ の範囲では破壊勒性は荷重線変位速度に依 存していないことが分かった。

\section{$4 \cdot 3$ 来待砂岩の破壊勒性試験に及ぼす温度の影響}

$4 \cdot 1$ および $4 \cdot 2$ に述べたように SENRBB 試験で得られた破壊 勒性は, $a / D=0.2$ から 0.4 の範囲ではノッチ長さの影響を受けず, また, $0.01 \mathrm{~mm} / \mathrm{min}$ から $0.09 \mathrm{~mm} / \mathrm{min}$ の範囲では荷重線変位速度 の影響を受けない。そこで，温度条件下で実施した破壊勒性試験 において, SENRBB 試験片のノッチ長さを $a / D=0.4$, 荷重線変位 速度を $0.075 \mathrm{~mm} / \mathrm{min}$ とした。なお，SCB 試験片から得られる破 壊勒性に及ぼすノッチ長さの影響に関しては Lim et al.(1994)によ り検討されており, その結果として, 破壊勒性は $a / R=0.5$ 程度で はノッチ長さの影響を受けないことが示されている。したがって， 本研究で用いた SCB 試験片のノッチ長さを $a / R=0.5$ とした。

Fig.11は，SENRBB 試験により得られた来待砂岩の破壊勒性と 試験温度との関係を示す。同図に示寸ように，来待砂岩の破壊勒 性は，温度が室温から $125^{\circ} \mathrm{C}$ 範囲で有意水準 $5 \%$ 検定の結果で は有意な変化は認められない。しかしながら, 温度 $125^{\circ} \mathrm{C}$ 以上に なると有意な変化を示しており温度の上昇とともに破壊勒性が増

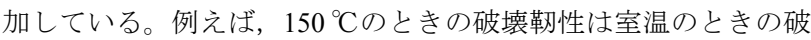
壊勒性と比べて約 $30 \%$ 増加しており，200 ${ }^{\circ} \mathrm{C}$ のきの破壊勒性は 室温のときの破壞勒性と比べて約 $40 \%$ 増加している。

Fig.12 は，SCB 試験により得られた来待砂岩の破壊勒性と温 度との関係を示す。同図に示すように, arrester の場合と short transverse の場合ともに, SCB 試験により得られた来待砂岩の破壊 勒性は，室温から $125^{\circ} \mathrm{C}$ 範囲ではほぼ一定の值をとっている。 一方，温度が $125^{\circ} \mathrm{C}$ 以上になると，温度の上昇とともに破壞勒性

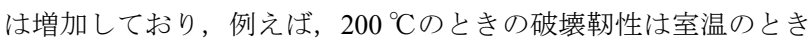

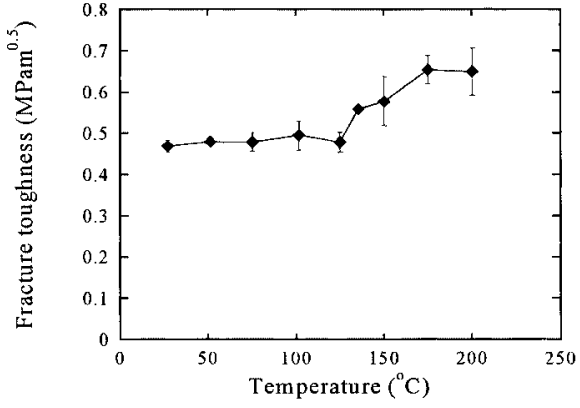

Fig.11 Variation of fracture toughness of Kimachi sandstone for SENRBB tests with temperature. $(a / D=0.4$, arrester orientation $)$

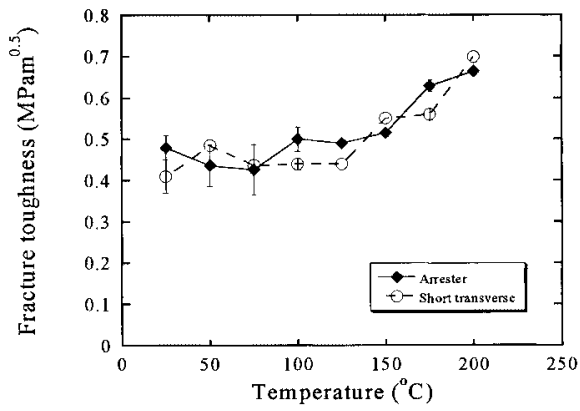

Fig.12 Variation of fracture toughness of Kimachi sandstone for SCB tests with temperature. $(a / R=0.5)$

の破壊勒性と比べて, arrester の場合約 $35 \%$ 増加しており, short transverse の場合約 $65 \%$ 増加している。この結果は, $a / D=0.4$ の 試験片を用いたSENRBB 試験により得られた破壊勒性とよく一致 しており, 温度の上昇にともなう破壊勒性の増加の傾向が示され ている。また, SENRBB 試験により得られた破壊勒性と SCB 試験 により得られた破壊勒性とを比較すると，それぞれ室温では 0.47 $\mathrm{MPam}^{0.5}$ と $0.48 \mathrm{MPam}^{0.5}, 100{ }^{\circ} \mathrm{C}$ では $0.49 \mathrm{MPam}^{0.5}$ と $0.50 \mathrm{MPam}^{0.5}$, さらに $200{ }^{\circ} \mathrm{C}$ では $0.65 \mathrm{MPam}^{0.5}$ と $0.66 \mathrm{MPam}^{0.5}$ であり, 両者の值 はほぼ等しい。一般に，岩石の破壊勒性は試験片の寸法や形状の 影響を強く受けるとされており（日本機械学会編集，1989)，異な る形状の試験片を用いた破壊勒性試験から，同程度の值の破壊勒 性を得ることは多くの場合難しい。しかし，本研究で行った SCB 試験と SENRBB 試験では, 異なる形状の試験片から同程度の值の 破壞勒性を得ることができた。

\section{5. 考察}

\section{$5 \cdot 1$ 試験片寸法と破壊勒性との関係}

本研究では，試験を温度条件下で行なうために試験槽の中で実 施したが，この試験槽の容量の関係から試験片の寸法を小さくす る必要があった。しかしながら, 岩石の破壊勒性は試験片寸法の 増大とともに増加することが知られている (高橋, 1987)。そこで, 本節では来待砂岩の破壊勒性に及ぼす寸法の影響を実験的に確認 するために, 試験片の直径を $30 \mathrm{~mm}, 40 \mathrm{~mm}, 50 \mathrm{~mm}$, および 60 $\mathrm{mm}$ と 4 種類設定して常温下で行った SENRBB 試験結果ならびに ISRM(International Society for Rock Mechanics)により岩石の標準的 な破壊勒性試験法として提案されている $\mathrm{CB}$ (Chevron Bend) 試験法 （ISRM,1988）により評価したレベル II 破壊勒性と比較した結果に ついて述べる。

Fig.13 は, 試験片寸法と破壊勒性との関係を示す。同図が示す ように, 試験片直径の増大に伴う破壊勒性の変化は, $10 \%$ 以内の 範囲に収まっており, 顕著な変化は認められなかった。また, ISRM 推奨案である CB 試験の結果は, レベル II 破壊勒性で $0.992 \mathrm{MPam}^{0.5}$ 


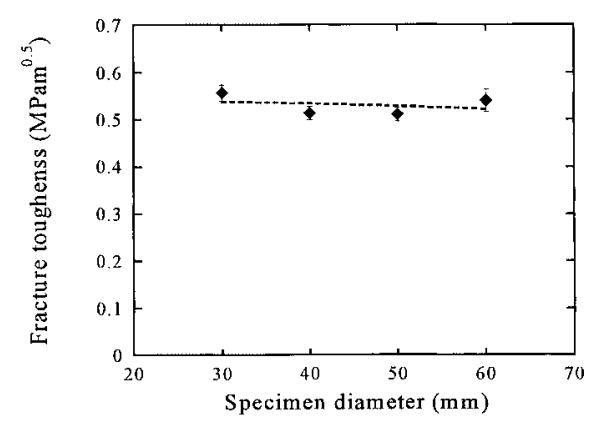

Fig.13 Variation of fracture toughness of Kimachi sandstone for SENRBB tests with specimen diameter.

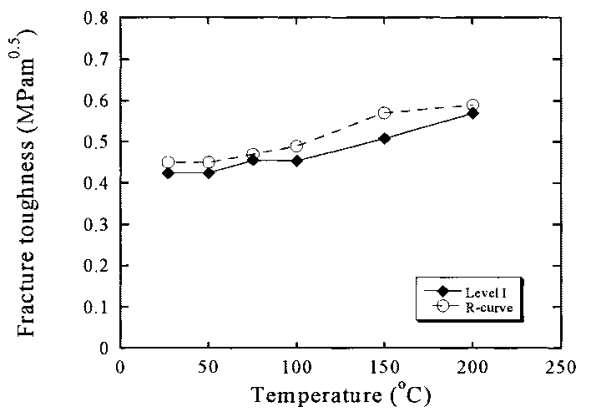

Fig.14 Comparison between level I fracture toughness and fracture toughness by R-curve method. (SENRBB tests, arrester orientation)

であり, SENRBB 試験から得られた破壊勒性と比較して約 45 〜 $50 \%$ 高い。

$5 \cdot 2$ レベル I 破壊勒性と R 曲線法による破壊勒性との比較

$4 \cdot 3$ で述べたように, 本研究では来待砂岩の破壊勒性に及ぼす 温度の影響についてレベルI破壊勒性に着目して試験を行ったが， 本節においては，き裂の進展を考慮した $\mathrm{R}$ 曲線による破壊勒性と レベル I 破壊勒性との比較結果について述べる。

前述した Fig.11 の破壊勒性は各温度条件で 3 回実施した試験結 果の平均值であるが, 3 回実施した試験の中の 1 回については, 試 験中に何回かの除荷一再載荷を行い, $\mathrm{R}$ 曲線法による破壊勒性の 評価を行った。Fig.14 は, R 曲線法を適用した試験から得られた 破壊勒性およびレベル I 破壊勒性と温度との関係を示す。同図が 示すように，す心゙ての温度条件で R 曲線法によって評価した破壊 勒性がレベル I 破壞勒性と比較して高い值をとっているが，両者 の差は $3 \%$ から $7 \%$ 程度であった。ただし, 温度 $150{ }^{\circ} \mathrm{C}$ のきの 両者の差は $12 \%$ である。

以上のことから，本試験で用いた来待砂岩の試験片の寸法およ び形状条件においては，レベル I 破壊勒性と R 曲線法による破壊 勒性の間に顕著な差は認められず，試験時におけるき裂の進展に 伴うき裂進展抵抗の増加は小さいものと考えられる。

\section{$5 \cdot 3$ 温度の上昇による来待砂岩の破壊勒性の増加}

4. で述べたように, 来待砂岩の破壞勒性は $a / D=0.4$ の試験片 を用いた SENRBB 試験および SCB 試験の結果では, 室温から 125 ${ }^{\circ} \mathrm{C}$ 以下では有意な変化は認められないが, それ以上の温度では, 温度の上昇とともに破壊勒性が増加する傾向を示している。この 結果は,例えば Meredith et al. による花崗岩と斑レイ岩の破壊勒性 が $100{ }^{\circ} \mathrm{C}$ 以上で温度の上昇とともに低下寸ることを示した研究結 果とは異なるものである。100 ${ }^{\circ} \mathrm{C}$ 以上における温度の上昇にとも なう花崗岩と斑レイ岩の破壊勒性低下の理由として, Meredith et al. は温度の上昇により生じる構成鉱物間の熱膨張の異方性が鉱物 粒子間にマイクロクラックを誘発し, それによってき裂の進展抵 抗が低下寸るためと考察している。この破壊勒性の低下につなが

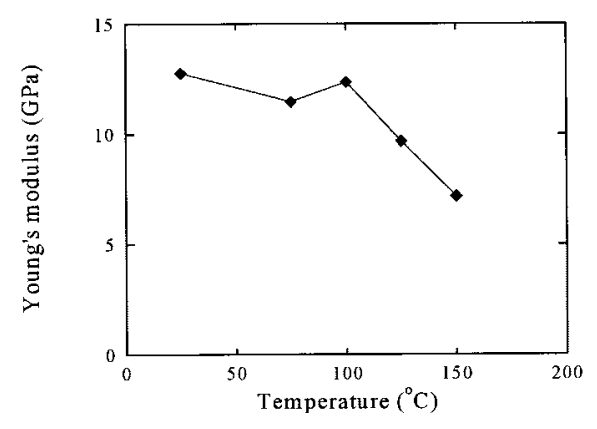

Fig.15 Variation of Young's modulus of Kimachi sandstone with temperature. (perpendicular to bedding plane)

る粒界き裂の発生は, 主として石英/長石間もしくは石英/石英間 で生じると述べている (Meredith et al., 1985)。

そこで, 本研究で用いた来待砂岩における温度上昇のマイクロ クラックの発生について検討するために, まず, $75^{\circ} \mathrm{C}, 100{ }^{\circ} \mathrm{C}$, $125^{\circ} \mathrm{C}$, および $150{ }^{\circ} \mathrm{C} の 4$ 種類の異なる温度条件下で一軸圧縮試 験を行い，温度によるヤング率の変化について調べた。試験片は 直径 $20 \mathrm{~mm}$, 長さ $45 \mathrm{~mm}$ の円柱形のもので, $40{ }^{\circ} \mathrm{C}$ 設定された乾 燥器内で試験片の重量の変化がなくなるまで乾燥させた後脱気を 行った。なお, 一軸圧縮試験時の軸ひずみを計測するために, ゲー ジ長 $5 \mathrm{~mm}$ の高温用ひずみゲージを試験片の相対する表面上の中 心に 2 枚貼り付けた。また, 一軸圧縮試験では温度を熱風によっ て調節したのでシリコン樹脂による被覆は行っていない。試験で は, まず, 破壊勒性試験と同一の昇温速度 $\left(1{ }^{\circ} \mathrm{C} / \mathrm{min}\right)$ で加熱し, その後 2 時間放置した後に試験を行った。一軸圧縮試験により得 られた初期接線ヤング率と温度との関係を Fig.15に示す。来待砂 岩の初期接線ヤング率は室温から温度 $100{ }^{\circ} \mathrm{C}$ 範囲ではほぼ一定 の值をとっているが, 温度 $100{ }^{\circ} \mathrm{C}$ 以上では初期接線ヤング率は温 度の上昇にともなって低下することが分かる。初期接線ヤング率 はクラック密度に依存するので (Lama and Vutukuri, 1992), ここ で示した温度 $100{ }^{\circ} \mathrm{C}$ 上におけるヤング率の低下は試験片内部で のマイクロクラックの発生と密接に関係していると考えられる。 また, 本研究では, 温度上昇に起因寸るマイクロクラックの発生 を確認するために, 試験片を昇温速度 $1{ }^{\circ} \mathrm{C} / \mathrm{min}$ で温度 $200^{\circ} \mathrm{C}$ まで 加熱した後, その状態で 2 時間放置した試験片の表面を冷却後, 顕微鏡によって加熱前の状態と観察比較した。Fig.16 は, 加熱前 (a) と加熱後 (b) の試験片表面の写真を示す。同図が示すように, 加熱前後の試験片表面を比較すると, 加熱後の試験片にはマイク ロクラックの発生 ( 矢印で示した個所) を確認することができる。 以上のように, 来待砂岩の場合も加熱することによりマイクロク ラックが発生している。

次に, 温度の上昇にともなう試験片のひずみの変化について検 討するために, $50{ }^{\circ} \mathrm{C}, 100{ }^{\circ} \mathrm{C}, 200{ }^{\circ} \mathrm{C} の 3$ 種類の温度条件を設定 し, ひずみの計測を行った。なお, 温度の設定条件は破壊勒性試 験と同一の昇温速度 $\left(1{ }^{\circ} \mathrm{C} / \mathrm{min}\right)$ で加熱し, その後 2 時間放置した。 ここで計測されたひずみは, 温度の変化による見かけひずみを含 んでいるので, 次式により温度補償を行った。

$$
\varepsilon_{m}(\Delta T)=\left\{\varepsilon_{i}(\Delta T)-\varepsilon_{t}(\Delta T)\right\} \cdot K_{0} / K_{t} \cdots
$$
ただし, $\Delta T$ は被測定物のひずみゲージ接着点の温度変化, $\varepsilon_{m}(\Delta T)$ は温度の変化によって生じたひずみ, $\varepsilon_{i}(\Delta T)$ はひずみ測定 器に指示されるひずみ, $\varepsilon_{t}(\Delta T)$ は温度による見かけひずみ, $K_{0}$ は 常温 $\left(24^{\circ} \mathrm{C}\right)$ によるゲージ率, $K_{t}$ は温度 $t$ におけるゲージ率であ る。なお, 本研究で用いたひずみゲージのデータシートによると, 測定温度 $50{ }^{\circ} \mathrm{C}$ では $\varepsilon_{t}(26)=-30 \times 10^{-6}, K_{50} / K_{24}=99.6$, 測定温度 $100{ }^{\circ} \mathrm{C}$ では $\varepsilon_{t}(76)=-40 \times 10^{-6}, K_{100} / K_{24}=99.0$, 測定温度 $200{ }^{\circ} \mathrm{C}$ 


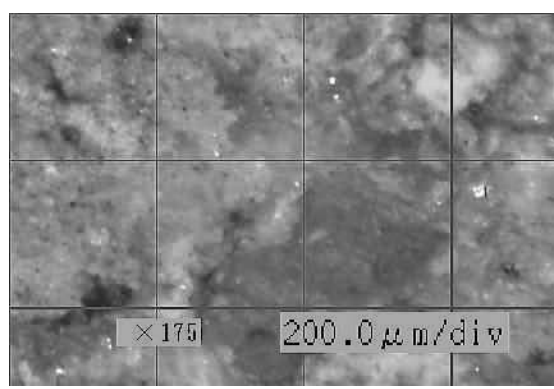

(a) Virgin state

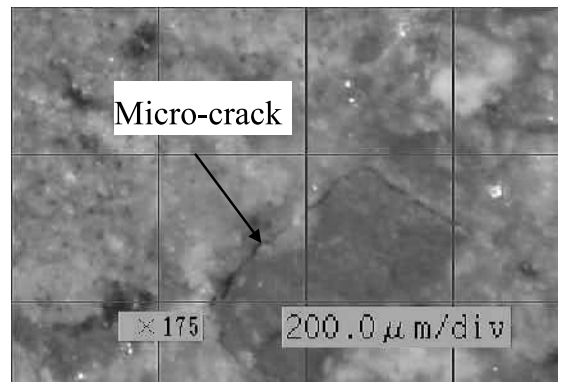

(b) After heating

Fig.16 Microphotographs of specimen surface in (a) virgin state and (b) after heating at $200 \mathrm{C}$ for 2 hours.

では $\varepsilon_{t}(176)=70 \times 10^{-6}, K_{200} / K_{24}=97.1$ である。

Fig.17に, 設定温度で 2 時間経過した後の軸ひずみと温度との 関係を示す。同図が示すように，稲田花崗岩の場合には，室温か ら $50{ }^{\circ} \mathrm{C}$ 範囲でひずみはほとんど変化していない。しかしなが ら, 温度 $50^{\circ} \mathrm{C}$ 以上では温度の上昇とともに試験片が膨張してい る。この結果は, 花崗岩では温度 $60 \sim 70{ }^{\circ} \mathrm{C}$ 前後からマイクロク ラックが発生するとした研究結果 ( 木下ら，1997）と調和的であ

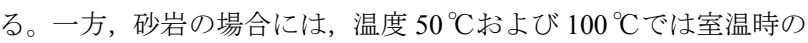
状態から試験片は膨張しているが，温度が $200{ }^{\circ} \mathrm{C}$ ま上昇すると 試験片は収縮している。来待砂岩は, 粘土鉱物, 主としてモンモ リロナイトを含んでいるが (松木ら，1998)，モンモリロナイトは 温度が $100{ }^{\circ} \mathrm{C}$ から $250{ }^{\circ} \mathrm{C}$ になると, 層間水や吸着水の脱水を起こ すことが知られている(図解応用地質用語編集委員会, 1985)。つ まり，温度の上昇によって試験片が収縮する理由として, $100{ }^{\circ} \mathrm{C}$ 以上の試験温度条件下では粘土鉱物からの層間水や吸着水の脱水 が発生していることが挙げられる。Fig.17 で示したひずみの計測

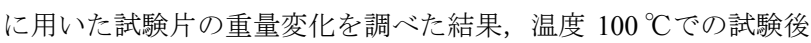
には $2.3 \%, 200{ }^{\circ} \mathrm{C}$ 試験後には $3.6 \%$ の重量低下が生じており層 間水や吸着水の脱水が確認できる。また，破壊勒性に及ぼす温度 の影響という点では，この粘土鉱物からの層間水や吸着水の脱水 によって粘土鉱物の状態変化 ( 粘土鉱物の乾燥・収縮による固結 化 ) が発生し，これによって砂岩の構成粒子間の結合強度が上昇 し，破壊勒性が増加するものと考えられる。

以上のように, 来待砂岩では破壊勒性の低下の要因となるマイ クロクラックの発生と, 破壞勒性の増加の要因となる粘土鉱物の 状態変化の両方が生じている。ただし，来待砂岩の破壊勒性が温 度 $125^{\circ} \mathrm{C}$ 以上で温度の上昇とともに増加したことを考慮すると, 来待砂岩の破壊勒性に及ぼす温度の影響としてはマイクロクラッ クの発生よりも粘土釷物の状態変化のほうがより支配的な要因で あると考えられる。

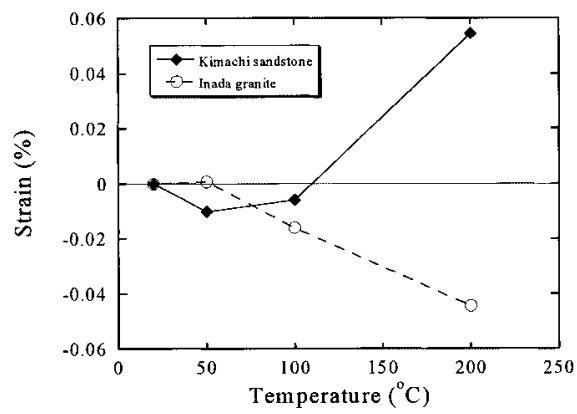

Fig.17 Variation of axial strain of Kimachi sandstone and Inada granite with temperature.

$$
\text { 6. 結 論 }
$$

本研究では, 来待砂岩の破壞勒性に及ぼす温度の影響について 明らかにするために, SENRBB 試験と SCB 試験の 2 種類の試験に よる検討を行った。その結果, 以下の事項が明らかになった。

（1） SCB 試験により得られた破壊勒性は， $a / D=0.4$ の試験片 を用いたSENRBB 試験により得られた破壊勒性と同程度の值をと り，温度の上昇にともなう破壊勒性の増加の傾向も類似したもの であった。

（2）試験片の直径を $30 \mathrm{~mm}$ から $60 \mathrm{~mm}$ まで変化させて行った SENRBB 試験の結果, 試験片直径の増大に伴う破壊勒性の変化は $10 \%$ 以内に収まっているが, レベル II 破壊勒性と比較すると約 45 〜 $50 \%$ 低い值となっている。

（3）レベル I 破壊勒性と R 曲線による破壊勒性とを比較した結 果, 両者に顕著な差は認められず，本試験で用いた来待砂岩にお ける試験片の寸法および形状条件においては, 試験時におけるき 裂の進展にともなうき裂進展抵抗の増加は小さいものと考えら れる。

（4）来待砂岩の破壊勒性は, 温度が $125^{\circ} \mathrm{C}$ までの範囲ではほぼ 一定の值を示すのに対し， $125^{\circ} \mathrm{C}$ 以上では温度の上昇にともなっ て破壊勒性は増加することが分かった。

（5）温度の上昇にともなう破壊勒性の変化の要因として, 温度 の上昇にともなうマイクロクラックの発生による破壊勒性の低下 と, 粘土鉱物に存在している吸着水や層間水が脱水するために起 こる粘土鉱物の状態変化による破壊勒性の増加の 2 つが挙げられ るが, 来待砂岩の場合には, 後者の方がより大きく影響を及ぼし たために，破壊勒性の増加が生じたものと考えられる。

\section{引 用 文 献}

Al-Shayea, N.A., Khan, K. and Abduljauwad, S.N.(2000) : Int. J. Rock Mech. and Min. Sci., Vol. 37, p. $629-643$

ISRM(1988) : Int. J. Rock Mech. \& Geomech. Abstr., Vol. 25, p. $71-96$

Chong, K.P. and Kuruppu, M.D.(1984) : Int. J. fracture, Vol. 26, p. 59-62

原子力委員会 (2000) : 原子力バックエンド対策専門部会資料, $7 \mathrm{p}$.

木下直人·安部 透·若林成樹·石田 毅 (1997): 土木学会論文集, Vol. 561, p. 151-162 LAMA, R.D. and Vutukuri, V.S. : 岩石・岩盤技術書のためのハンドブック 岩の力学的 性質 II, 古今書院 (東京), 92p.

Lim, L.I., Johnston, I.W. , Choi, S.K. and Boland, J.N. (1994) : Int. J. Rock Mech. \& Geomech. Abstr., Vol. 31, p. 185-197

松木浩二. 坂口清敏 - 飯野英樹 - 奥村清彦 (1998): 資源と素材, Vol. 114, No. 12, p. $895-900$

松木浩二・野津山喜晴・高橋秀明 (1989)：土木学会論文集, Vol. 406, p. 35-41

Meredith, P.G. and Atkinson, B.K. (1985) : Physics of the Earth and Planetary Interiors, Vol. 39 , p. $33-51$

日本機械学会編 (1989) : 岩石破壊力学とその応用, コロナ社 (東京), 36p. Ouchterlony, F.(1981) : ASTMSTP, Vol. 75, p. 237-256

酒井 昇 (1987): 応用地質, Vol. 28, p. 19-24

Sun, Z. and Ouchterlony, F.(1986) : Int. J. Rock Mech. Min. Sci. \& Geomech. Abstr., Vol. 23, p. $399-409$

高橋秀明 (1987) : 第 102 回特別講演会 講演要旨集, 日本機械学会 (東京), 34p.

山口梅太郎・宮崎道雄 (1970) : 日本鉱業会誌, Vol. 86, p. 346-351

図解応用地質用語編集委員会 (1985) : 図解用語集シリーズ 図解応用地質用語集 : 東 洋書店 (東京), $501 \mathrm{p}$ 